Article

\title{
Effective Dye Degradation by Graphene Oxide Supported Manganese Oxide
}

\author{
Hayarpi Saroyan ${ }^{1}$, George Z. Kyzas ${ }^{2}\left(\mathbb{D}\right.$ and Eleni A. Deliyanni ${ }^{1, *}$ (1) \\ 1 Laboratory of Chemical Technology, Department of Chemistry, Aristotle University of Thessaloniki, \\ 54124 Thessaloniki, Greece; haysarsam@yahoo.com \\ 2 Hephaestus Advanced Laboratory, Eastern Macedonia and Thrace Institute of Technology, 65404 Kavala, \\ Greece; kyzas@teiemt.gr \\ * Correspondence: lenadj@chem.auth.gr; Tel.: +30-2310-997808
}

Received: 1 December 2018; Accepted: 11 January 2019; Published: 14 January 2019

\begin{abstract}
Graphene oxide (GO) was used as a support for manganese oxide $\left(\mathrm{MnO}_{2}\right)$ for the preparation of a nanocomposite catalyst for the degradation of an azo dye, Reactive Black 5 (RB5). The nanocomposite was characterized for the structure by XRD, for the morphology with SEM, and for the surface chemistry with FTIR and potentiometric titration measurements. The GO-MnO nanocomposite presented a high catalytic activity for the degradation/oxidation of RB5 at ambient conditions, which was higher than that of the pure $\mathrm{MnO}_{2}$ and could be attributed to the beneficial contribution of the manganese oxide and the graphene oxide.
\end{abstract}

Keywords: manganese oxide; graphene oxide; dyes; degradation; reuse; characterization

\section{Introduction}

It is widely known that an important problem of environmental science is the existence of high toxic compounds in effluents. In particular, a special class of pollutants that can cause carcinogenetic problems is dyes. The synthetic dyes that exist in wastewaters are considered to be a big hazard due to the pollution of the water resources. Among the huge variety of dyes in wastewaters, synthetic azo dyes, which are extensively applied in industry (dyeing and textile processes), are highly persistent in the aquatic environment and have possible mutagenic and carcinogenic effects [1]. Azo dyes are organic molecules/compounds with one or more azo group $(-\mathrm{N}=\mathrm{N}-)$ that is directly united with aromatic rings (benzene and/or naphthalene) as well as some other functional groups (amino, hydroxyl, carboxyl, chlorine, sulfonate, etc.) with excellent solubility in the water.

The recent research contains various methods for reducing the impact of azo dyes on public health and environmental quality. Common classes of techniques are physical-based (adsorption, ion exchange, membrane filtration [2-6]), chemical-based (ozonation, electrochemical degradation, advanced oxidation processes), and biological-based (biodegradation, bioaccumulation, biosorption using fungi, algae, yeast, and bacteria) [7-10]. Due to the many drawbacks presented in conventional wastewater treatment technologies (high operation costs, energy consumption, reduced efficiency due to the chemical stability of dyes and/or the complexity of their degradation), the recent trend is to combine the techniques for sustainability, as oxidation/catalysis or adsorption/catalysis, etc.

In the last decades, a huge number of catalysts were synthesized using oxides of $\mathrm{Ti}, \mathrm{Zn}$, and $\mathrm{Mn}[9,11-13]$ as the bases. Manganese dioxide $\left(\mathrm{MnO}_{2}\right)$ is a promising material because of it is low cost, it presents high stability, and it has environmental compatibility as well as abundant availability [14]. Nano-manganese dioxide have been studied as adsorbents [15,16] and oxidants/degradants [17-20] for a great variety of organic pollutants and dyes due to its octahedral crystal structure $\left(\mathrm{MnO}_{6}\right)$ and its high redox potential [21]. $\mathrm{MnO}_{2}$ is usually synthesized at nanoscale in order for more reaction sites to 
be obtained [22,23], presenting difficulties in separation from aquatic solutions. An alternative method for solving this problem is the preparation of composites with graphite and/or graphene oxide (GO). GO contains reactive oxygen functional groups (hydroxyl, carboxyl, epoxy groups) attached to an $\mathrm{sp}^{2} / \mathrm{sp}^{3}$ hybridized carbon network that provides hydrophilic character and chemical reactivity [24-26]. It is a fact that GO has an important impact on many applications nowadays, such as batteries [27], nanofiltration [28], electrodialysis [29], imaging [30], etc. GO- $\mathrm{MnO}_{2}$ nanocomposites are easier to separate from water, and their high conductivity can accelerate electron transfer [31,32], which is beneficial for the oxidation of organic molecules. Therefore, GO is an important and promising support for $\mathrm{MnO}_{2}$ nanoparticles as an effective catalyst for the adsorption and degradation improvement. In the present study, a GO-MnO 2 nanocomposite was prepared and applied as the catalyst for Reactive Black Five (RB5) oxidation, which was selected as a model organic molecule. RB5 was selected as a model azo-dye. The aim of our study was to examine the possible synergetic effect of adsorption and oxidative degradation. Adsorption of RB5 was previously examined from our team as a model azo-dye pollutant for the adsorption method (with various adsorbent materials). For this reason, RB5 was selected as a solute. The nanocomposite (catalyst) was characterized for the structure by XRD, for the morphology with SEM, and for the surface chemistry with FTIR and potentiometric titration measurements. The full series of degradation experiments ( $\mathrm{pH}$, ionic strength, kinetics) was performed in order to examine the degradation ability of GO-MnO 2 for RB5. The GO-MnO 2 nanocomposite exhibited high potential in RB5 degradation.

\section{Materials and Methods}

\subsection{Materials}

RB5 and $\mathrm{KMnO}_{4}$ were purchased from Chem-Lab NV (Zedelgem, Belgium), graphite, $\mathrm{H}_{2} \mathrm{O}_{2}$, and $\mathrm{NaCl}$ were purchased from Sigma Aldrich (St. Louis, $\mathrm{MO}, \mathrm{USA}$ ), and $\mathrm{MnSO}_{4}$ was purchased from Merck (Darmstadt, Germany). All reagents were of analytical grade $\geq 98.5 \%$.

\subsection{Synthesis of $\mathrm{GO}, \mathrm{MnO}_{2}$, and $\mathrm{GO}-\mathrm{MnO}_{2}$}

The GO was prepared by oxidation of graphite according to the modified Hummers method [33]. Briefly, graphite powder $(10 \mathrm{~g})$ was added in sulfuric acid $\left(230 \mathrm{~mL}, 0{ }^{\circ} \mathrm{C}\right)$ under stirring, followed by potassium permanganate $(30 \mathrm{~g})$ addition. Finally, hydrogen peroxide $(100 \mathrm{~mL}, 30 \mathrm{wt} \%$ solution) was added, and the GO particles formed were separated by decantation and transferred to dialysis tubes (D9402-100FT Sigma-Aldrich (St. Louis, MO, USA), until sulfate ions were removed. When the solution was clear, the wet form of graphite oxide was separated by filtration, freeze-dried, and denoted as GO.

In the case of manganese oxide $\left(\mathrm{MnO}_{2}\right)$ preparation, a $30 \mathrm{~mL}$ solution of $\mathrm{KMnO}_{4}\left(0.21 \mathrm{~mol} \mathrm{~L}^{-1}\right)$ was added dropwise to a $0.2 \mathrm{~mol} \mathrm{~L}^{-1}$ solution of $\mathrm{MnSO}_{4}$ under stirring. $\mathrm{MnO}_{2}$ was formed according to the reaction in Equation (1) [34]:

$$
2 \mathrm{KMnO}_{4}+3 \mathrm{MnSO}_{4}+2 \mathrm{H}_{2} \mathrm{O} \rightarrow 5 \mathrm{MnO}_{2}+\mathrm{K}_{2} \mathrm{SO}_{4}+2 \mathrm{H}_{2} \mathrm{SO}_{4}
$$

For the synthesis of GO-MnO 2 composite, $2 \mathrm{~g}$ of graphite oxide was dispersed in $175 \mathrm{~mL}$ of deionized water and then ultra-sonicated for $1 \mathrm{~h}$. A solution of $\mathrm{KMnO}_{4}\left(0.8 \mathrm{~g}\right.$ of $\mathrm{KMnO}_{4}$ dissolved in $100 \mathrm{~mL}$ deionized water) was slowly added into the above dispersion under vigorous stirring and kept in darkness under ambient conditions for $12 \mathrm{~h}$. The product was collected by centrifugation, washed with deionized water and absolute ethanol, and freeze-dried [35]. The resulted material was denoted as $\mathrm{GO}-\mathrm{MnO}_{2}$.

\subsection{Characterizations}

XRD measurements were conducted at a PW1820 X-ray diffractometer (Philips, New York, NY, USA) with a $\mathrm{Cu} \mathrm{K} \alpha$ radiation for crystalline phase identification at a scan rate of $2^{\circ} \mathrm{min}^{-1}$. SEM 
images were performed with an electron microscope (JEOL JSM-840A, Tokyo, Japan) with an energy dispersive X-ray (EDX) micro-analytical system. EDX analysis was done at magnification $10 \mathrm{~K}$ and led to the maps of elements for the determination of Mn distribution on the surface. FTIR spectra were taken with a Nicolet 560 (Thermo Fisher Scientific Inc., Madison, WI, USA) FTIR spectrometer. Potentiometric titration measurements were carried out with a T50 automatic titrator (Mettler Toledo, Columbia, SC, USA) [36].

\subsection{Degradation Activity}

\subsubsection{Effect of $\mathrm{pH}$}

The effect of $\mathrm{pH}$ was tested by dispersing $0.01 \mathrm{~g}$ of $\mathrm{MnO}_{2}$ and/or GO-MnO${ }_{2}$ in $20 \mathrm{~mL}$ (V) of RB5 solution $\left(\mathrm{C}_{0}=60 \mathrm{mg} \mathrm{L}^{-1}\right)$ in capped vials. The $\mathrm{pH}$ value was adjusted between 3 and 9 by additions of $\mathrm{HNO}_{3}\left(0.01 \mathrm{~mol} \mathrm{~L}^{-1}\right)$ or $\mathrm{NaOH}\left(0.01 \mathrm{~mol} \mathrm{~L}^{-1}\right)$. The suspensions were shaken for $24 \mathrm{~h}$ (agitation rate: $\mathrm{N}=160 \mathrm{rpm}$ ) in a water bath at $25^{\circ} \mathrm{C}$. After, they were centrifuged in order to separate the solid catalysts, and the residual dye concentration was detected by UV-vis spectrophotometer (model U-2000, Hitachi, Tokyo, Japan) at $603 \mathrm{~nm}$. The RB5 removal percentage (R\%) was calculated by Equation (2):

$$
\mathrm{R}(\%)=\frac{\mathrm{C}_{0}-\mathrm{C}_{\mathrm{e}}}{\mathrm{C}_{0}} \cdot 100 \%
$$

where $\mathrm{C}_{0}$ and $\mathrm{C}_{\mathrm{e}}\left(\mathrm{mg} \mathrm{L}^{-1}\right)$ are the initial and equilibrium concentrations of RB5, respectively.

\subsubsection{Effect of Ionic Strength}

The effect of ionic strength was examined by dispersing $0.01 \mathrm{~g}$ of $\mathrm{MnO}_{2}$ and/or $\mathrm{GO}-\mathrm{MnO}_{2}$ with $20 \mathrm{~mL}(\mathrm{~V})$ of RB5 solution $\left(\mathrm{C}_{0}=60 \mathrm{mg} \mathrm{L}^{-1}\right)$ with an addition of $\mathrm{NaCl}$ concentrations from 0.01 and $1 \mathrm{M}$. The suspensions were shaken for $24 \mathrm{~h}$ (agitation rate: $\mathrm{N}=160 \mathrm{rpm}$ ) into a water bath to control the temperature at $25^{\circ} \mathrm{C}$ at $\mathrm{pH}=3$.

\subsubsection{Kinetics}

For decolorization experiments, $0.01 \mathrm{~g}$ of adsorbent was dispersed in $20 \mathrm{~mL}(\mathrm{~V})$ of RB5 solution $\left(C_{0}=20,40\right.$ or $\left.100 \mathrm{mg} \mathrm{L}^{-1}\right)$ in capped vials. After shaken for $24 \mathrm{~h}$ at $25^{\circ} \mathrm{C}$ at $160 \mathrm{rpm}$ for different times ( $5 \mathrm{~min}-24 \mathrm{~h}$ ), the dispersions were centrifuged, and the residual dye concentration was measured by UV-vis at $603 \mathrm{~nm}$. The kinetic results were fitted to pseudo-first order [37] (Equation (3)) and pseudo-second order [38] (Equation (4)) kinetic models:

$$
\begin{gathered}
C_{t}=C_{0}-\left(C_{0}-C_{e}\right)\left(1-e^{-k_{1} t}\right), \\
C_{t}=C_{0}-\left(C_{0}-C_{e}\right)\left(1-\frac{1}{1+k_{2} t}\right),
\end{gathered}
$$

where $\mathrm{k}_{1}, \mathrm{k}_{2}\left(\mathrm{~min}^{-1}\right)$ are the rate constants for the pseudo-first and -second order kinetic equations; $\mathrm{C}_{0}, \mathrm{C}_{\mathrm{t}}, \mathrm{C}_{\mathrm{e}}(\mathrm{mg} / \mathrm{L})$ are the initial, transient, and equilibrium concentrations of dye in the aqueous solution, respectively.

\section{Results and Discussion}

\subsection{Characterizations}

The XRD patterns of GO, $\mathrm{MnO}_{2}$, and GO- $\mathrm{MnO}_{2}$ are presented in Figure 1. The characteristic (001) peak of graphite oxide centered at $2 \theta=10.3^{\circ}$ is indicative of the successful oxidation of graphite into graphite oxide [39]. 


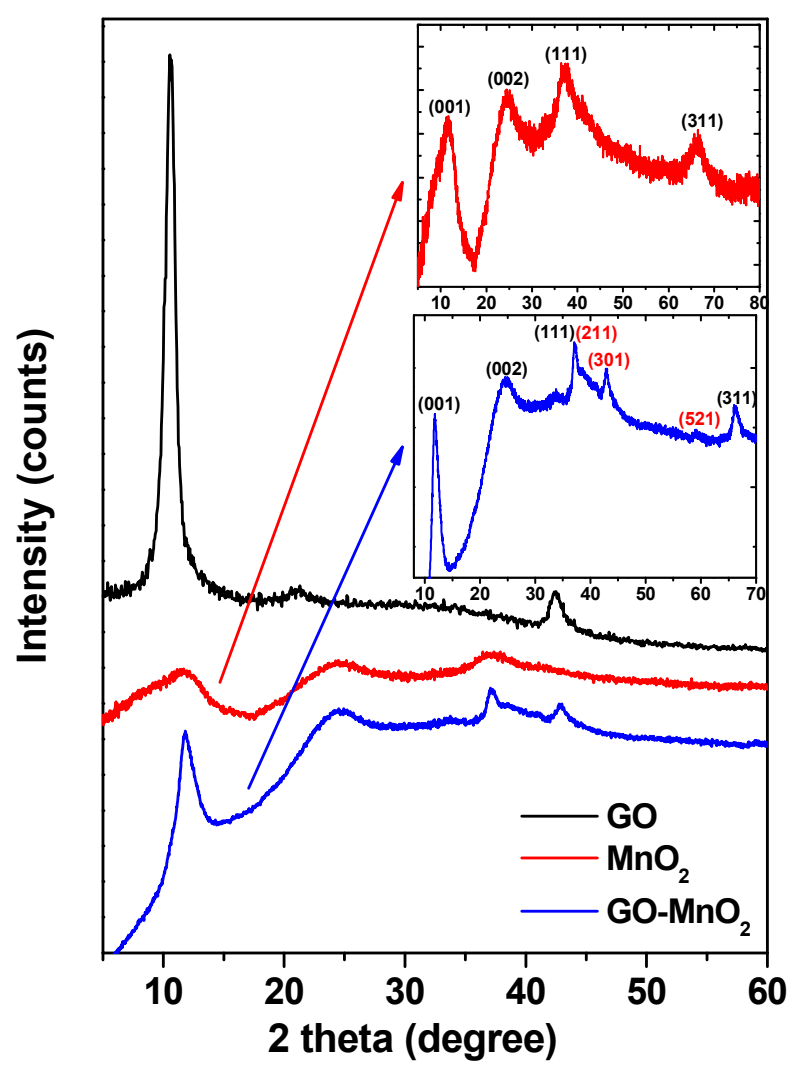

Figure 1. XRD patterns of graphite oxide (GO), manganese oxide $\left(\mathrm{MnO}_{2}\right)$, and $\mathrm{GO}-\mathrm{MnO}_{2}$ nanocomposite. $2 \theta$ (degrees).

In the diffraction pattern for $\mathrm{MnO}_{2}$, the basal reflections at $2 \theta=11.4^{\circ}, 25^{\circ}, 37.2^{\circ}$, and $66.7^{\circ}$ (inset in Figure 1) could be attributed to the (001), (002), (111), and (311) basal reflections diffraction bands of $\delta-\mathrm{MnO}_{2}$ (birnessite JCPDS 80-1098), respectively [40,41]. The broadness of the peaks indicated the low crystallinity of the manganese oxide. The average crystallite size (D) of $\mathrm{MnO}_{2}$ was estimated by applying the Debye Scherrer's equation for the (111) peak. The crystallite size of $\mathrm{MnO}_{2}$ was found to be about $65 \mathrm{~nm}$. The XRD spectra for GO-MnO 2 composite presented a diffraction peak at around $11^{\circ}$, which was attributed to the (001) of GO. The peak appeared at a slightly higher reflection angle with a lower intensity than in GO, demonstrating that GO in GO-MnO was partially exfoliated. Furthermore, the diffraction peaks could be indexed to $\delta-\mathrm{MnO}_{2}$ (birnessite JCPDS 80-1098). The peaks were less broad than those of $\mathrm{MnO}_{2}$, indicating the poor crystallinity and the high dispersion of the inorganic phase around the graphitic layers in the obtained composite. The diffraction patterns resembled those referenced in literature that were assigned the peaks to birnessite type $\mathrm{MnO}_{2}$ [42]. This result agreed well with the reported $\mathrm{MnO}_{2}$ on graphene [43,44]. The crystallite size was calculated from the major (211) diffraction peak using the Debye Scherrer approximation and was found to be about $205 \mathrm{~nm}$. The total $\mathrm{Mn}$ content for the GO- $\mathrm{MnO}_{2}$ nanocomposite, calculated by atomic absorption spectroscopy (AAS) measurement, was found to be $200 \mathrm{mg}$ Mn per gram of nanocomposite.

The morphology, size, and microstructure of the nanocomposite catalyst were also characterized by SEM, and the results are presented in Figure 2. SEM images of the GO- $\mathrm{MnO}_{2}$ nanocomposite revealed a partially layered structure of this nanocomposite, which was indicative of the partial exfoliation of GO in the composite. The energy dispersive spectroscopy (EDS) spectra of GO-MnO 2 revealed that the detectable elements were manganese, carbon, and oxygen, with the carbon originating from the GO nanosheets, the oxygen from $\mathrm{GO}$ and $\mathrm{MnO}_{2}$, and the manganese from $\mathrm{MnO}_{2}$. The uniform distribution of $\mathrm{MnO}_{2}$ nanoparticles was testified in the SEM-elemental maps of the manganese for the nanocomposite (Figure 2c), which revealed $\mathrm{MnO}_{2}$ nanoparticles to be uniformly distributed on the surface of GO nanosheets. 
The textural changes, illustrated by the pore size distribution curves derived from density functional theory (DFT) calculations, are presented in Figure 3b. The GO- $\mathrm{MnO}_{2}$ composite was more porous than the parent $\mathrm{GO}$ and less porous than $\mathrm{MnO}_{2}$. During the composite formation, $\mathrm{GO}$ was oxidized, and defects that were created in the graphene layers contributed to the increase in porosity. $\mathrm{MnO}_{2}$ prepared could be considered a porous oxide with a surface area comparable to those previously reported $[45,46]$.

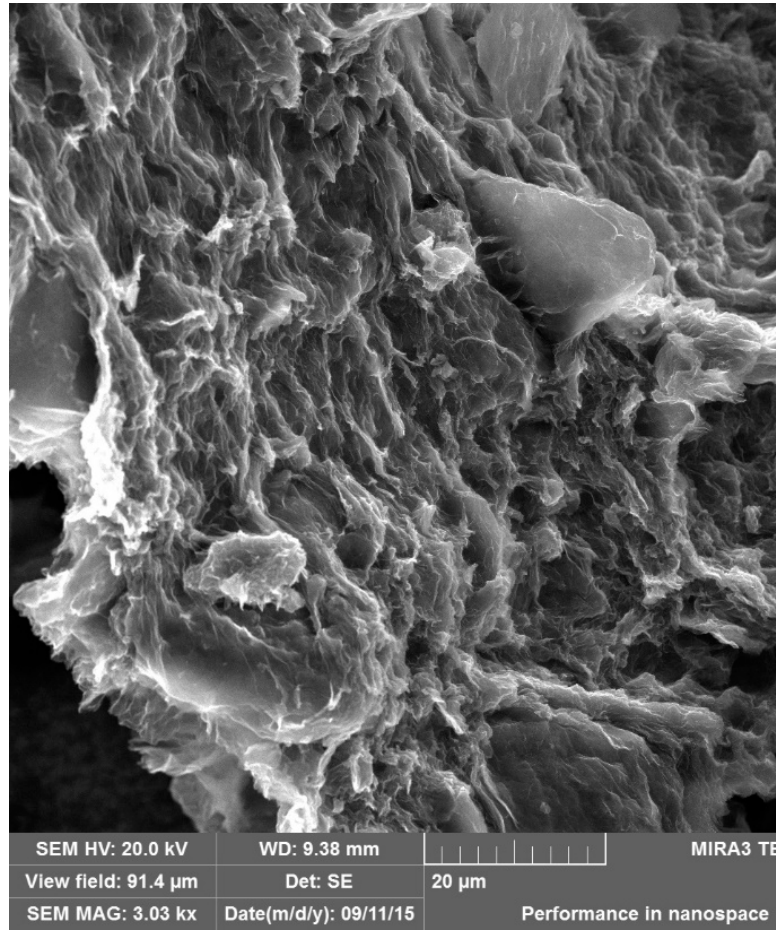

(a)

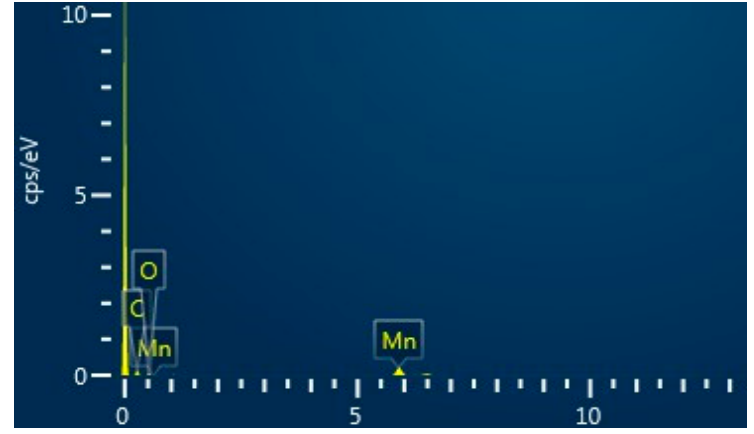

(b)

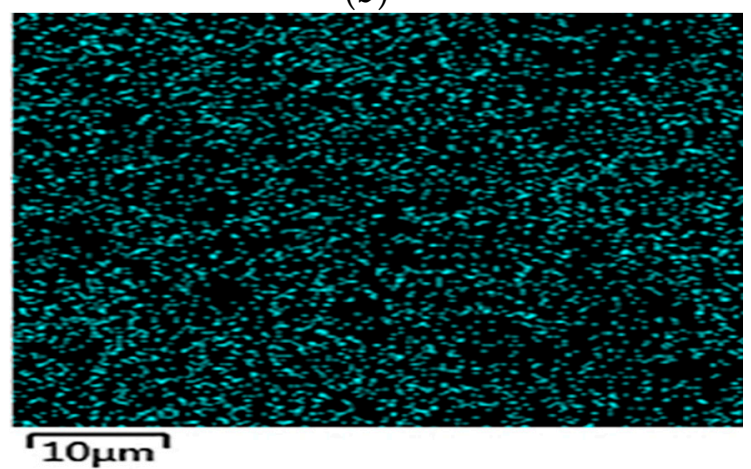

(c)

Figure 2. (a) SEM images of GO-MnO 2 nanocomposite; (b) SEM-EDS; (c) SEM-maps of the manganese distribution on the GO-MnO nanocomposite.

The $\mathrm{N}_{2}$ adsorption isotherms for $\mathrm{MnO}_{2}$ and $\mathrm{GO}-\mathrm{MnO}_{2}$ are seen in Figure 3a, and the pore size distribution is seen in Figure $3 b$. The $\mathrm{N}_{2}$ adsorption isotherms for $\mathrm{MnO}_{2}$ indicated a lack of micropores and an increased nitrogen uptake at $\mathrm{P} / \mathrm{P}_{0}>0.95$, which is indicative of external surface area. The isotherm for the $\mathrm{GO}-\mathrm{MnO}_{2}$ composite did not present a variation in nitrogen uptake in the initial part of the isotherm-indicative of a lack of micropores. The textural parameters of the GO, $\mathrm{MnO}_{2}$, and the GO- $\mathrm{MnO}_{2}$ nanocomposite are seen in Table 1. Table 1 conveys that the specific surface area for the $\mathrm{GO}-\mathrm{MnO}_{2}$ composite was $25.85 \mathrm{~m}^{2} \mathrm{~g}^{-1}$. It is seen that the specific surface area and the total pore volume of GO support increased slightly after impregnation with $\mathrm{MnO}_{2}$. 

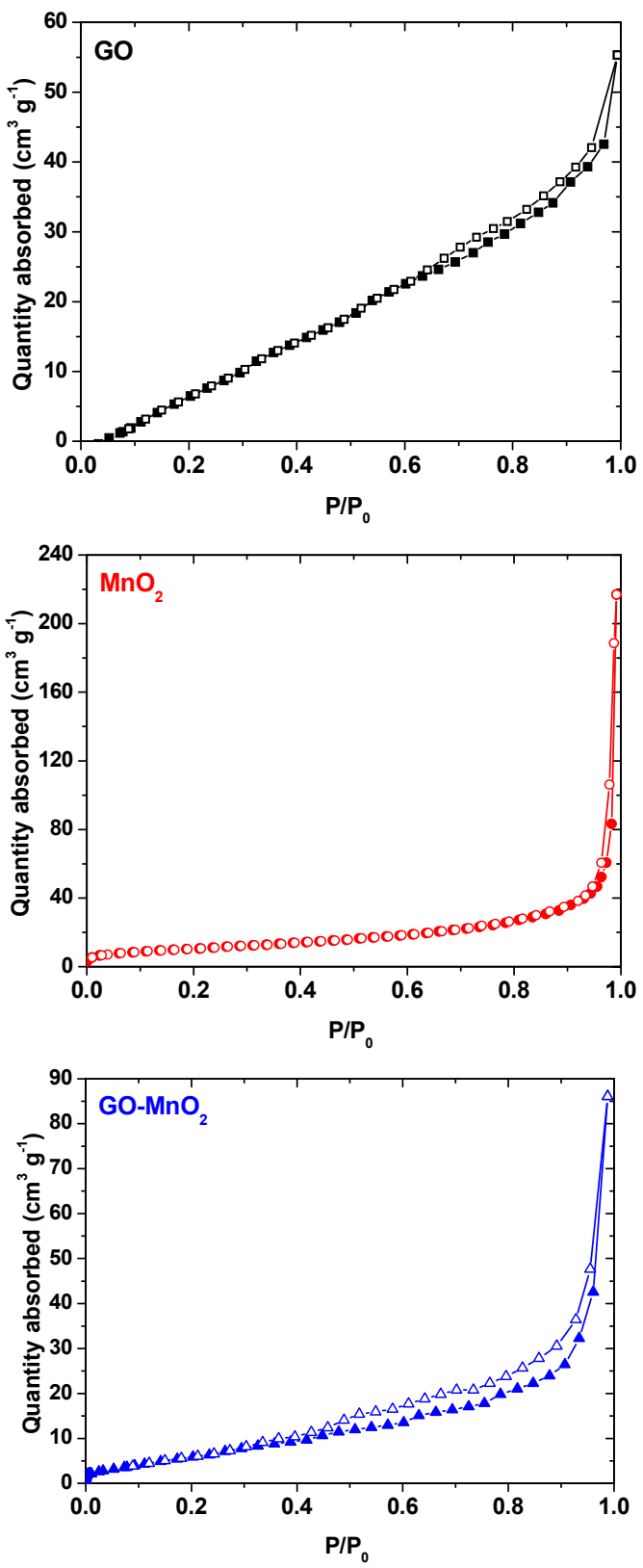

(a)

Figure 3. Cont. 


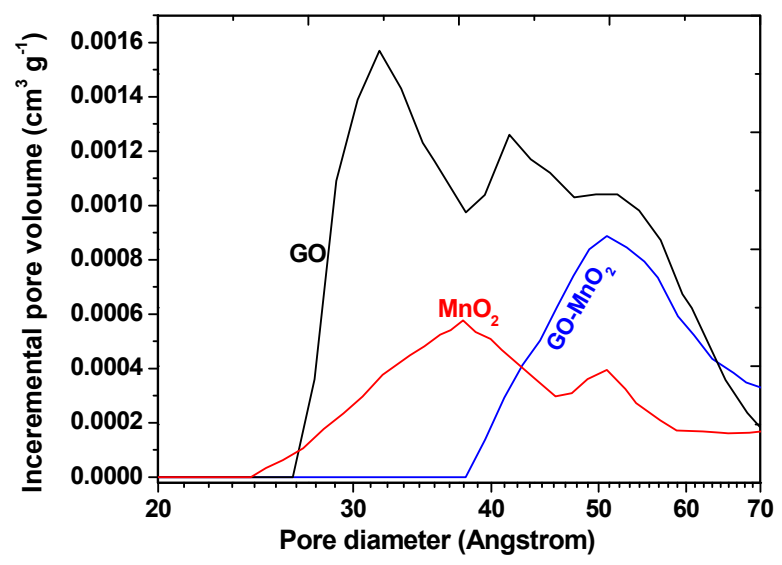

(b)

Figure 3. (a) $\mathrm{N}_{2}$ adsorption isotherms for $\mathrm{GO}$ (black line), $\mathrm{MnO}_{2}$ (red line) and $\mathrm{GO}-\mathrm{MnO}_{2}$; (blue line); (b) pore size distribution for $\mathrm{GO}, \mathrm{MnO}_{2}$, and $\mathrm{GO}-\mathrm{MnO}_{2}$.

Table 1. Textural parameters of $\mathrm{GO}, \mathrm{MnO}_{2}$, and $\mathrm{GO}-\mathrm{MnO}_{2}$.

\begin{tabular}{ccccc}
\hline Sample & $\mathbf{S}_{\text {BET }}\left(\mathbf{m}^{\mathbf{2}} \mathbf{g}^{-\mathbf{1}}\right)$ & $\mathbf{V}_{\text {total }}\left(\mathbf{c m}^{\mathbf{3}} \mathbf{g}^{-\mathbf{1}}\right)$ & $\mathbf{V}_{\text {meso }}\left(\mathbf{c m}^{\mathbf{3}} \mathbf{g}^{-\mathbf{1}}\right)$ & $\mathbf{V}_{\text {micro }}\left(\mathbf{c m}^{\mathbf{3}} \mathbf{g}^{\mathbf{- 1}}\right)$ \\
\hline $\mathrm{GO}$ & 20.93 & 0.088 & 0.024 & 0.065 \\
$\mathrm{MnO}_{2}$ & 38.50 & 0.336 & 0.336 & 0 \\
$\mathrm{GO}_{2}$ & 25.85 & 0.133 & 0.133 & 0 \\
\hline
\end{tabular}

From the textural results, we concluded that the small surface area and the volume of pores of GO- $\mathrm{MnO}_{2}$ could not be the main parameters for the high performance of the composite. For this reason, the surface chemistry was further investigated.

Differential thermogravimetric (DTG) curves (measured in nitrogen atmosphere) for $\mathrm{MnO}_{2}$, GO- $\mathrm{MnO}_{2}$, and GO are presented in Figure 4 for the sake of comparison. For all materials, the peaks at about $100{ }^{\circ} \mathrm{C}$ represented the removal of adsorbed water, while for $\mathrm{MnO}_{2}$, the peak at about $200{ }^{\circ} \mathrm{C}$ represented the dehydration of crystal water of manganese oxide [47,48]. For GO-MnO 2 , the peak at about $200-250{ }^{\circ} \mathrm{C}$ was due to the mass loss from the removal of the oxygen-containing functional surface groups. For the GO- $\mathrm{MnO}_{2}$ composite, a decrease in the peak intensity was seen and was due to the decrease in the oxygen containing surface groups after the composite formation. The complex peaks between 300 and $600{ }^{\circ} \mathrm{C}$ may represent the reduction of $\mathrm{Mn}$ (IV) to $\mathrm{Mn}$ (II) with a loss of oxygen [49]. $\mathrm{MnO}_{2}$ was reduced to $\mathrm{Mn}_{2} \mathrm{O}_{3}$ [30] and then to $\mathrm{Mn}_{3} \mathrm{O}_{4}$ and $\mathrm{MnO}$. Then, $\mathrm{Mn}$ (II) was reduced between 750 and $800{ }^{\circ} \mathrm{C}$.

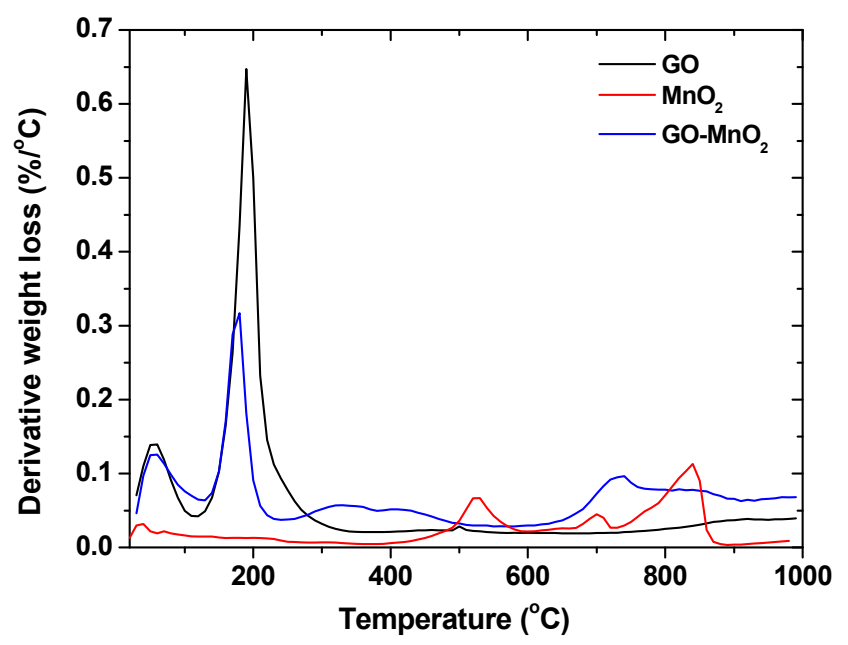

Figure 4. Differential thermogravimetric (DTG) curves for $\mathrm{GO}, \mathrm{MnO}_{2}$, and $\mathrm{GO}-\mathrm{MnO}_{2}$ nanocomposite. 


\subsection{Dye Degradation}

The influence of several parameters-such as $\mathrm{pH}$, ionic strength, and contact time-on the removal of $\mathrm{RB} 5$ by $\mathrm{MnO}_{2}$ and $\mathrm{GO}-\mathrm{MnO}_{2}$ nanocomposite was initially investigated in order for the best performance conditions to be testified.

\subsubsection{Effect of $\mathrm{pH}$ and Ionic Strength}

The effect of the solution $\mathrm{pH}$ in a range of 3-9 on RB5 removal by $\mathrm{MnO}_{2}$ and $\mathrm{GO}-\mathrm{MnO}_{2}$ is shown in Figure 5a. With an increase in the $\mathrm{pH}$ value, the $\mathrm{RB} 5$ removal of $\mathrm{GO}-\mathrm{MnO}_{2}$ decreased from about $85 \%$ at $\mathrm{pH} 3.0$ to about $60 \%$ at $\mathrm{pH} 9.0$ with the maximum uptake at $\mathrm{pH}$ 3.0. These results suggested that RB5 removal from the aqueous solution by $\mathrm{GO}-\mathrm{MnO}_{2}$ was facilitated in acidic solutions. The same trend was observed for the other materials. The oxidation of organic pollutants by $\mathrm{MnO}_{2}$ is usually $\mathrm{pH}$-dependent [50] because of the $\mathrm{pH}$-dependent redox potential of $\mathrm{MnO}_{2} / \mathrm{Mn}^{2+}$ and the speciation of organic pollutants [51]. The $\mathrm{pH}$-dependence of $\mathrm{RB} 5$ removal by $\mathrm{GO}-\mathrm{MnO}_{2}$ may be connected to either the degree of RB5 elimination (due to the oxidizing ability of $\mathrm{MnO}_{2}$ and thereby the $\mathrm{pH}$ of the solution, since reduction of $\mathrm{MnO}_{2}$ to $\mathrm{Mn}^{2+}$ requires the participation of protons), or to the fact that the $\mathrm{RB} 5$ oxidation by GO- $\mathrm{MnO}_{2}$ is considered a surface reaction connected to the surface chemical nature and charge.

Solution $\mathrm{pH}$ is important for adsorption as well as for degradation because it influences the surface charge of the adsorbent. Thus, we concluded that RB5 sorption on $\mathrm{GO}-\mathrm{MnO}_{2}$ depends on the surface charge of $\mathrm{GO}-\mathrm{MnO}_{2}$ at different $\mathrm{pH}$ values and also on the surface charge of $\mathrm{RB} 5$ species. Potentiometric titration results indicated that the total surface charge $\left(\mathrm{Q}_{\text {surf }}\right)$ of $\mathrm{GO}-\mathrm{MnO}_{2}$ was negative for the $\mathrm{pH}$ range $>5$ (Figure $5 \mathrm{~b}$ ) due to oxygen-containing surface functional groups. At $\mathrm{pH}$ values $>5$, these groups were deprotonated, and negative surface charges were formed that resulted in electrostatic repulsions with the negatively charged surface groups of RB5 molecules. Consequently, there was a decrease in the adsorption ability of $\mathrm{GO}-\mathrm{MnO}_{2}$ at this $\mathrm{pH}$ range. At $\mathrm{pH}$ values $<5$, these oxygencontaining functional groups were protonated, and positive surface charges were formed that resulted in electrostatic attractions with the negatively charged surface groups of RB5 molecules. Consequently, there was an increase in the adsorption ability of $\mathrm{GO}-\mathrm{MnO}_{2}$ at this $\mathrm{pH}$ range. For $\mathrm{pH}$ values $<5$, since the $\mathrm{pKa}$ of $\mathrm{RB} 5$ is 10.16 , at these $\mathrm{pH}$ values $(\mathrm{pH}<\mathrm{pKa})$, the interactions between $\mathrm{RB} 5$ molecule and the composite's surface were between $-\mathrm{OH}_{2}{ }^{+}$surface groups of the composite and the molecular form of the dye molecule. Garcia et al. [52] calculated the partial negative charges of the RB5 molecule, as sulfonate $(-0.8677)$, sulfate $(-0.8641)$, sulfonic $(-0.8294)$, and hydroxyl $(-0.2496)$. The adsorption of the dye onto a positively charged surface could be attributed to the sulfonate groups it possesses due to the larger density of electronic charges [53]. Since the maximum removal for $\mathrm{GO}-\mathrm{MnO}_{2}$ was attained at a $\mathrm{pH}$ of 3.0, equilibrium and kinetic experiments were performed at this $\mathrm{pH}$.

For GO- $\mathrm{MnO}_{2}$ nanocomposite, the adsorption capacity was found to increase slightly with the increase in $\mathrm{NaCl}$ concentration, as presented in Figure $5 \mathrm{c}$. This may have been due to the salting out effect of electrolytes via the decrease in the solubility of RB5 [54]. Since the adsorption performance of GO- $\mathrm{MnO}_{2}$ was the best at $1 \mathrm{~mol} \mathrm{~L}^{-1} \mathrm{NaCl}$, all experiments were performed under these conditions. 


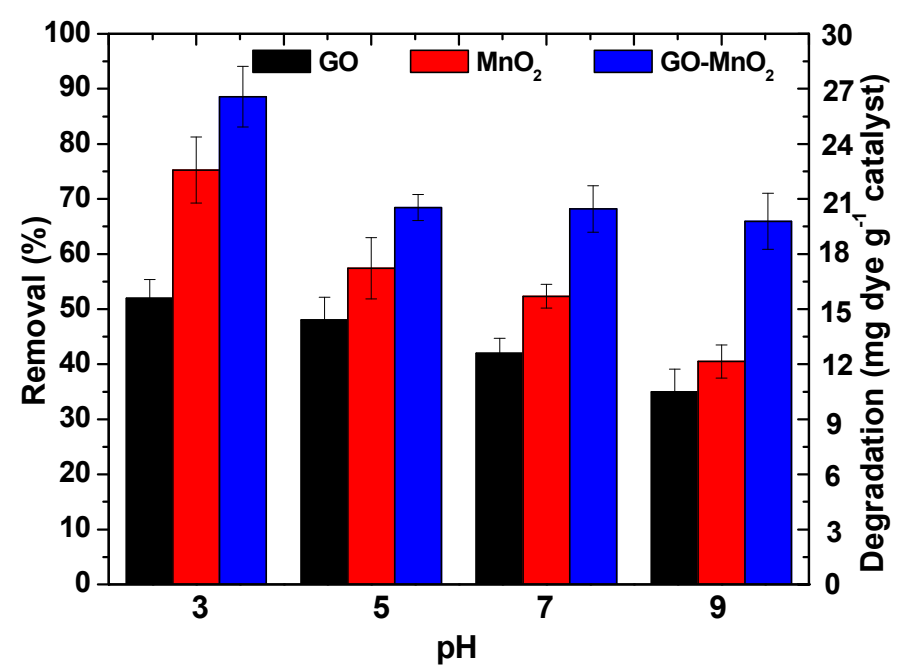

(a)

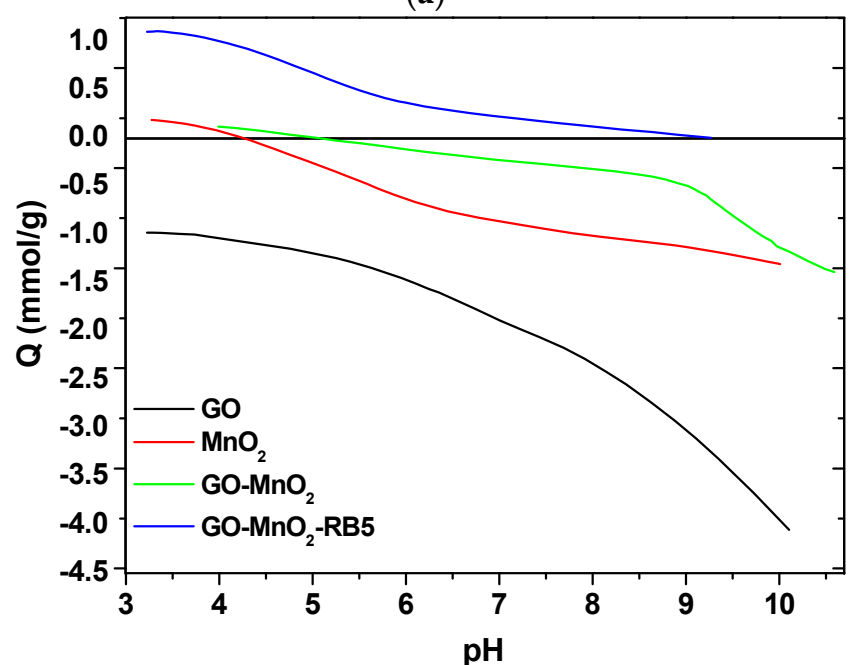

(b)

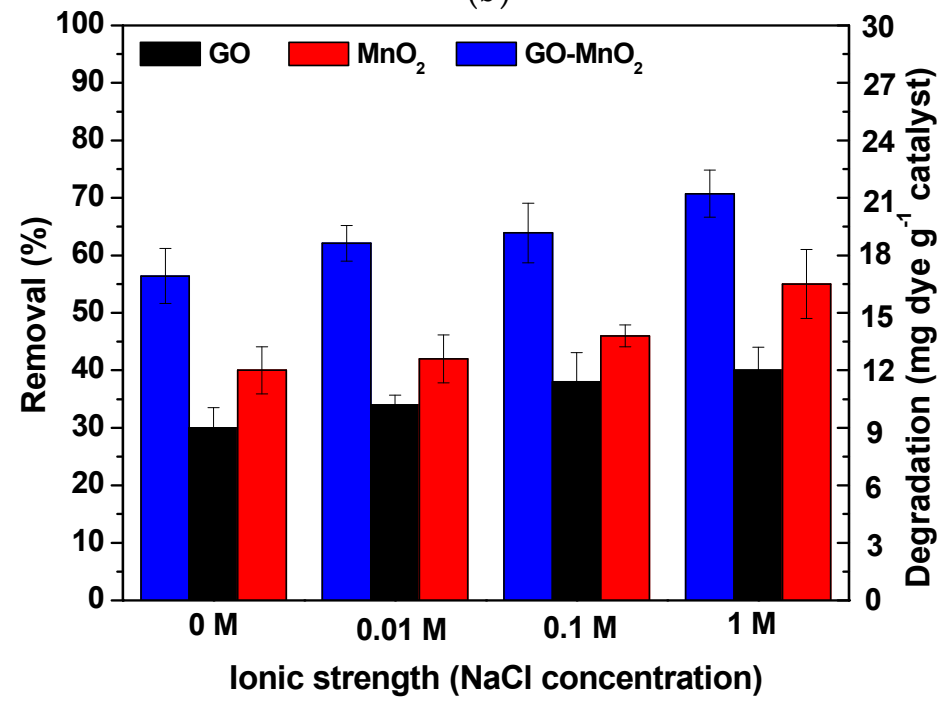

(c)

Figure 5. (a) Effect of initial $\mathrm{pH}$ on Reactive Black 5 (RB5) removal onto $\mathrm{MnO}_{2}$ and $\mathrm{GO}-\mathrm{MnO}_{2}$ nanocomposite $\left(\mathrm{V}=20 \mathrm{~mL} ; \mathrm{C}_{0}=60 \mathrm{mg} \mathrm{L}^{-1}\right)$; (b) proton uptake curves for $\mathrm{MnO}_{2}$ and $\mathrm{GO}-\mathrm{MnO}_{2}$ nanocomposite; (c) effect of ionic strength on RB5 adsorption/degradation onto GO-MnO $\mathrm{M}_{2}(\mathrm{~V}=20 \mathrm{~mL}$; $\left.\mathrm{C}_{0}=60 \mathrm{mg} \mathrm{L}^{-1}\right)$. 


\subsubsection{Effect of Contact Time-Effect of $\mathrm{H}_{2} \mathrm{O}_{2}$}

The experimental results presented in Figure 6 indicate that RB5 degradation on GO- $\mathrm{MnO}_{2}$ reached equilibrium in $60 \mathrm{~min}$. The results were fitted to the pseudo-first-order and pseudo secondorder kinetic models. The pseudo second-order kinetic model was found to better describe the results. The kinetic parameters are shown in Table 2.

Table 2. Kinetic parameters for the RB5 degradation related to Figure 6a,b.

\begin{tabular}{cccccc}
\hline & & \multicolumn{2}{c}{ Pseudo-First Order } & \multicolumn{2}{c}{ Pseudo-Second Order } \\
\cline { 2 - 5 } & & $\mathbf{k}_{\mathbf{1}}$ & $\mathbf{R}_{\mathbf{2}}$ & $\mathbf{k}_{\mathbf{2}}$ & $\mathbf{R}_{\mathbf{2}}$ \\
\hline Curve & Figure & $\mathbf{m i n}^{-\mathbf{1}}$ & - & $\mathbf{m i n}^{\mathbf{1}}$ & - \\
\hline $100 \mathrm{mg} \mathrm{L}^{-1} \mathrm{RB} 5\left(+\mathrm{H}_{2} \mathrm{O}_{2}\right)$ & $7 \mathrm{a}$ & 0.45993 & 0.998 & 1.34084 & 0.995 \\
$100 \mathrm{mg} \mathrm{L}^{-1} \mathrm{RB5}$ & - & 0.05804 & 0.974 & 0.09595 & 0.976 \\
$60 \mathrm{mg} \mathrm{L}^{-1} \mathrm{RB}^{2}\left(+\mathrm{H}_{2} \mathrm{O}_{2}\right)$ & - & 0.28312 & 0.994 & 0.78528 & 0.997 \\
$60 \mathrm{mg} \mathrm{L}^{-1} \mathrm{RB}^{-}$ & - & 0.05333 & 0.979 & 0.09390 & 0.975 \\
$20 \mathrm{mg} \mathrm{L}^{-1} \mathrm{RB}^{2}\left(+\mathrm{H}_{2} \mathrm{O}_{2}\right)$ & - & 0.05450 & 0.965 & 0.09543 & 0.979 \\
$20 \mathrm{mg} \mathrm{L}^{-1} \mathrm{RB}$ & - & 0.04981 & 0.991 & 0.08536 & 0.979 \\
$\mathrm{MnO}_{2}$ & $7 \mathrm{~b}$ & 0.20301 & 0.983 & 0.40697 & 0.994 \\
$\mathrm{MnO}_{2}+\mathrm{H}_{2} \mathrm{O}_{2}$ & - & 0.42056 & 0.999 & 1.81215 & 0.998 \\
$\mathrm{GO}^{\mathrm{GO}-\mathrm{MnO}_{2}}$ & - & 0.06076 & 0.991 & 0.11268 & 0.980 \\
$\mathrm{GO}-\mathrm{MnO}_{2}\left(+\mathrm{H}_{2} \mathrm{O}_{2}\right)$ & - & 0.05802 & 0.974 & 0.09595 & 0.976 \\
$\mathrm{GO}+\mathrm{MnO}_{2}\left(+\mathrm{H}_{2} \mathrm{O}_{2}\right)$ & - & 0.45993 & 0.997 & 1.34084 & 0.995 \\
& - & 0.07789 & 0.970 & 0.14492 & 0.992 \\
\hline
\end{tabular}

The application of GO- $\mathrm{MnO}_{2}$ nanocomposite was also studied for the $\mathrm{RB} 5$ and degradation with the addition of $\mathrm{H}_{2} \mathrm{O}_{2}$ at a concentration that was estimated for the mineralization of the dye from the equation:

$$
2 \mathrm{C}_{26} \mathrm{H}_{21} \mathrm{O}_{19} \mathrm{~N}_{5} \mathrm{~S}_{6} \mathrm{Na}_{4}+87 \mathrm{H}_{2} \mathrm{O}_{2} \rightarrow 52 \mathrm{CO}_{2}+108 \mathrm{H}_{2} \mathrm{O}+8 \mathrm{Na}+10 \mathrm{~N}+12 \mathrm{~S},
$$

and was found to be $0.15 \mathrm{M}$.

The concentration of RB5 in the solution was measured at a certain reaction time, and the results are presented in Figure 6a. For an initial concentration of $60 \mathrm{mg} \mathrm{L}^{-1}$, about $70 \%$ of RB5 was removed by $\mathrm{GO}-\mathrm{MnO}_{2}$ without the presence of $\mathrm{H}_{2} \mathrm{O}_{2}$ after $2 \mathrm{~h}$, while the addition of $0.15 \mathrm{M} \mathrm{H}_{2} \mathrm{O}_{2}$ increased the percentage removal to about $99 \% . \mathrm{H}_{2} \mathrm{O}_{2}$ improved the RB5 degradation due to $\bullet \mathrm{OH}$ creation, according to a possible route described by Equation (6) [55]:

$$
\mathrm{RB} 5-\mathrm{OH}+\bullet \mathrm{OH}-\mathrm{H}_{2} \mathrm{O} \rightarrow \bullet \mathrm{RB} 5=\mathrm{O}+\bullet \mathrm{OH} \rightarrow \mathrm{CO}_{2}+\mathrm{H}_{2} \mathrm{O} .
$$

The application of GO-MnO 2 for RB5 degradation was also studied with the addition of $\mathrm{H}_{2} \mathrm{O}_{2}$ for 20 and $100 \mathrm{mg} \mathrm{L}^{-1}$ initial RB5 solution concentrations, and the results are presented in Figure 6a. These results convey that the increase in the initial concentration resulted in a decrease in the percentage of removal/degradation of the dye. Experiments in the presence of $\mathrm{H}_{2} \mathrm{O}_{2}$-but in the absence of catalyst - presented no decolorization of the solution. In presence of catalysts, the addition of $\mathrm{H}_{2} \mathrm{O}_{2}$ resulted in an increase in the removal/degradation. The percentage increase was different for the different initial concentration. The lower concentration resulted in a lower increase, indicating that the ratio $\mathrm{C}_{0} \mathrm{RB} 5 / \mathrm{mM} \mathrm{H}_{2} \mathrm{O}_{2}$ is a crucial parameter. 


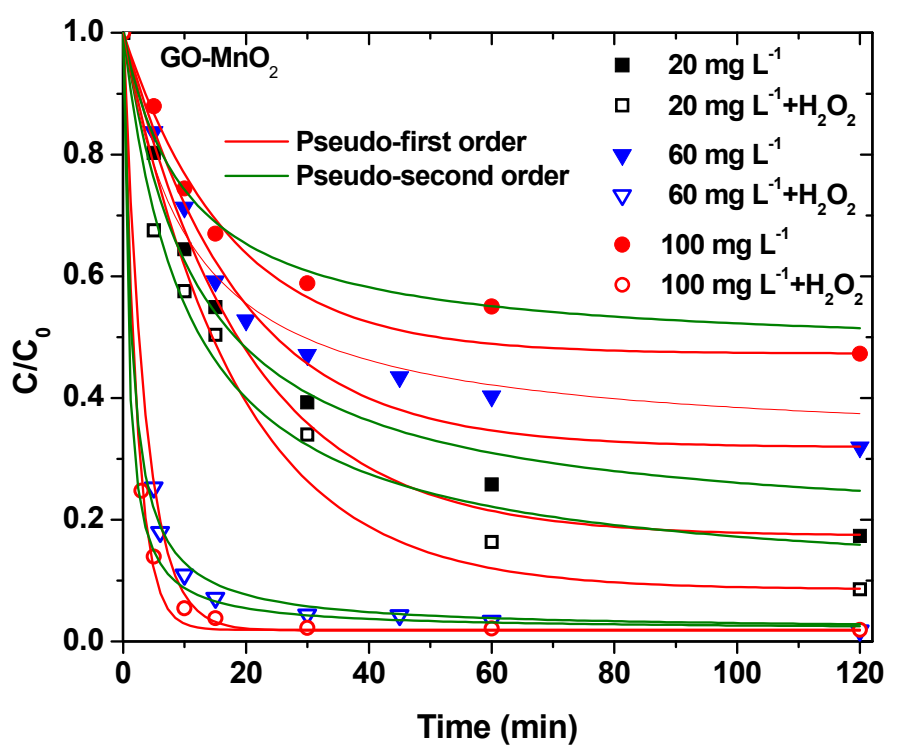

(a)

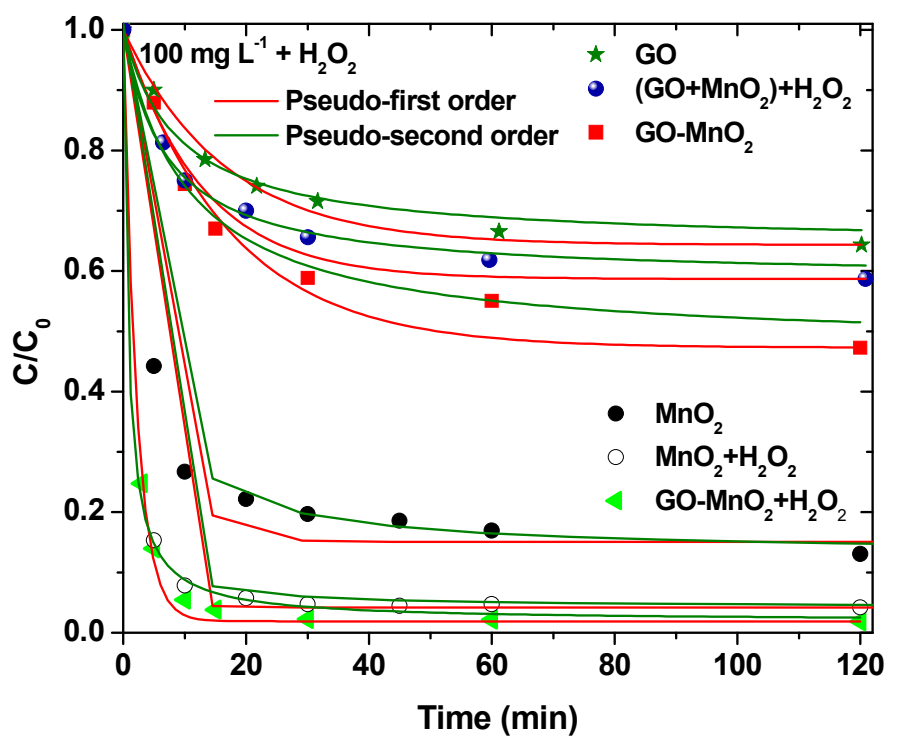

(b)

Figure 6. (a) Effect of $\mathrm{H}_{2} \mathrm{O}_{2}$ at different initial concentrations on $\mathrm{RB} 5$ removal by GO- $\mathrm{MnO}_{2}$; (b) effect of the comparison between the nanocomposite catalyst and the mixture of the raw materials performance on RB5 degradation.

The degradation activity of the $\mathrm{GO}-\mathrm{MnO}_{2}$ was also investigated spectroscopically by monitoring the decolorization efficiency in UV-Vis spectra $(250-750 \mathrm{~nm})$. Figure 7a shows the UV-vis spectra of the 100,60, and 20 ppm RB5 aqueous solutions after $2 \mathrm{~h}$ contact time, with $\mathrm{GO}-\mathrm{MnO}_{2}$ suspension at $\mathrm{pH} 3$ in the absence of $\mathrm{H}_{2} \mathrm{O}_{2}$, along with the UV-vis spectra of the 100 ppm RB5 initial solution. From Figure 7a, it is seen that for the initial RB5 solution, the maximum absorbance was presented at $\lambda_{\max } \sim 599 \mathrm{~nm}$ in the visible region, which could be attributed to the $-\mathrm{N}=\mathrm{N}-$ azo bond of the dye. The intensity of this peak was relative to the azo dye concentration in the solution [56,57], and the blue color of the dye was attributed to the $n \rightarrow p$ transition of the non-bonding electrons to the anti-banding pi-group orbital of the double bond system. With the decrease in the concentration of the initial RB5 solution, the intensity of this band decreased due to the decolorization of the solution and the possible cleavage of the azo bonds for the formation of $-\mathrm{NH}_{2}$ groups. 
In the presence of $\mathrm{H}_{2} \mathrm{O}_{2}$ (Figure $7 \mathrm{~b}$ for $100 \mathrm{mg} \mathrm{L}^{-1}$ initial RB5 concentration), within $120 \mathrm{~min}$, the band seemed to be disappearing, suggesting a nearly complete decolorization of RB5. The bands at 230 and $310 \mathrm{~nm}$, which could be attributed to the benzene and naphthalene aromatic rings of RB5 [58-60], were also not present, while new absorption bands were presented at $\sim 267$ and $\sim 354 \mathrm{~nm}$, which could be attributed to aromatic amines and amino-naphthalene sulfonates [61].

The RB5 degradation activity of pure GO and of a mixture of $\mathrm{GO}$ and $\mathrm{MnO}_{2}$ was tested in the presence of $\mathrm{H}_{2} \mathrm{O}_{2}$. The results are illustrated in Figure 7c, from which it is clear that the nanocomposite presented a better performance from its precursor materials as well as from a mixture of the precursor materials at the same weight percentage as in the nanocomposite, which suggests the beneficial properties of the prepared nanocomposite. The above presented results are in agreement with those presented by Zhang et al. [62] (with amorphous zero-valent iron) and Ben Mbarek et al. [63] (with $\mathrm{Mn}-\mathrm{Al}$ particles as the decolorizing material for RB5 aqueous solutions).

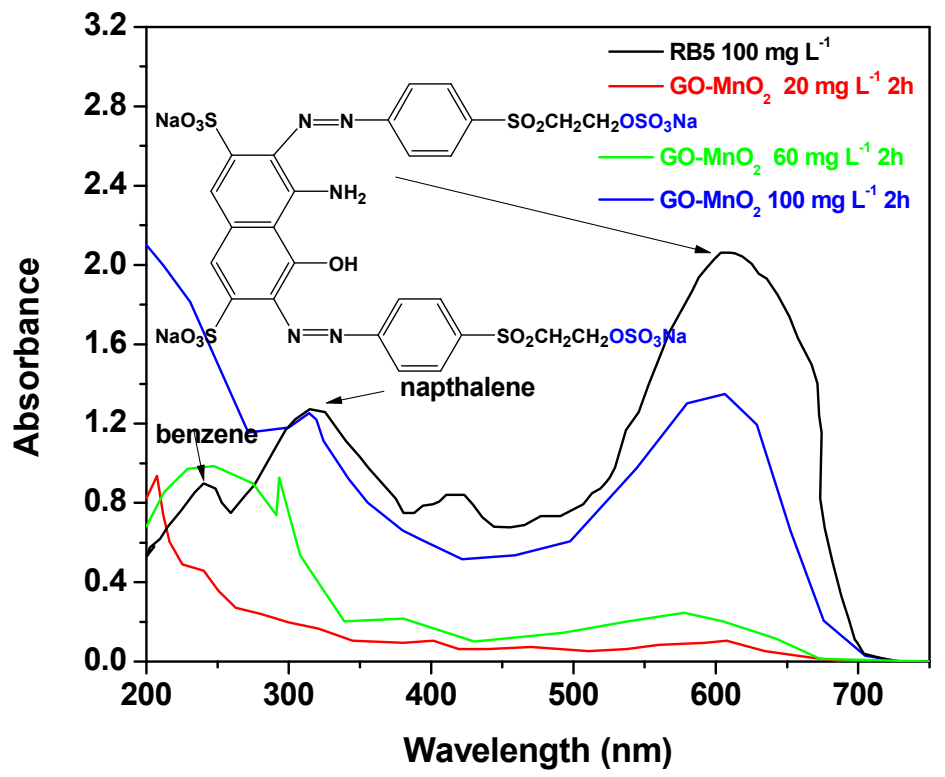

(a)

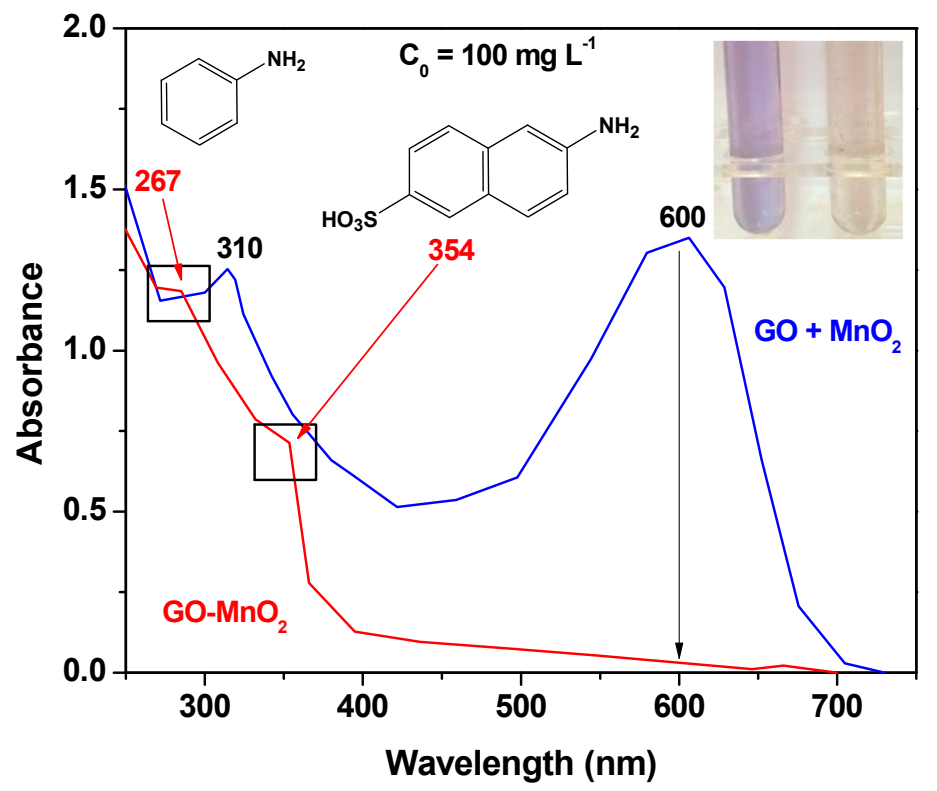

(b)

Figure 7. Cont. 


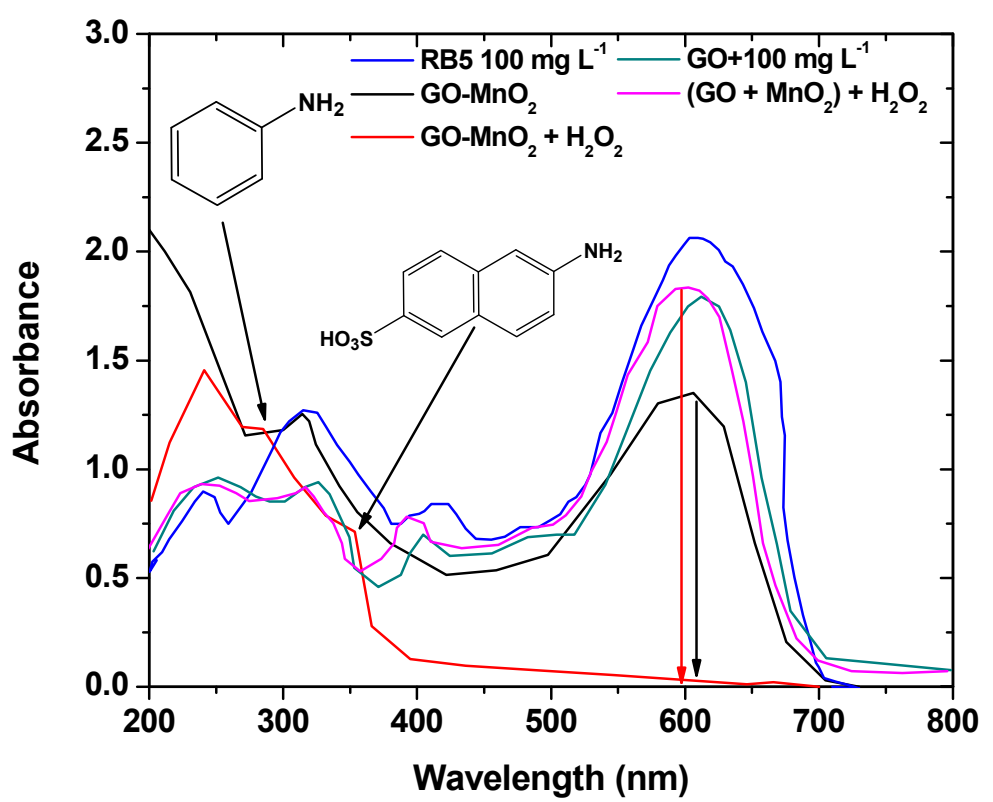

(c)

Figure 7. UV-Vis spectra illustrating: (a) the effect of different initial dye concentration; (b) the effect of $\mathrm{H}_{2} \mathrm{O}_{2}$ on RB5 degradation; (c) the comparison between the performance of the nanocomposite catalyst and the mixture of the raw materials on RB5 degradation.

\subsection{Analysis of Surface Features}

Figure 8 shows the FTIR spectra of GO-MnO 2 nanocomposite. The spectrum for GO-MnO nanocomposite shows the characteristic absorption bands corresponding to graphite oxide from its oxygen-containing functional groups at $1055,1220,1380$, and $1724 \mathrm{~cm}^{-1}$ due to the stretching vibration of alkoxy ( $\mathrm{C}-\mathrm{O}), \mathrm{C}-\mathrm{O}$ (epoxy), the deformation vibration of $\mathrm{O}-\mathrm{H}$ carboxyl $(\mathrm{C}-\mathrm{OH})$, and the $\mathrm{C}=\mathrm{O}$ stretching vibration of $\mathrm{COOH}$ groups (carbonyl $\mathrm{C}=\mathrm{O}$ ), respectively [47]. It should be noted that the bands between 1150 and $1380 \mathrm{~cm}^{-1}$ corresponding to the stretching vibration bands of $\mathrm{C}-\mathrm{O}$ (epoxy) and to the deformation vibration of $\mathrm{O}-\mathrm{H}$ carboxyl $(\mathrm{C}-\mathrm{OH})$ were less intense for the composites, indicating that these groups were involved in the nanocomposite formation. Moreover, the peak at about $725 \mathrm{~cm}^{-1}$ was attributed to the Mn-O-Mn band [64], and the symmetric vibration of Mn-O-H appeared at about $1060 \mathrm{~cm}^{-1}$ [65]. The presence of $\mathrm{Mn}-\mathrm{O}-\mathrm{H}$ indicated that $\mathrm{Mn}$ atoms of the $\mathrm{MnO}_{6}$ octahedron may have interacted with $\mathrm{O}$ atoms of the residual functional groups via a hydrogen bond or a covalent coordination bond [66]. 


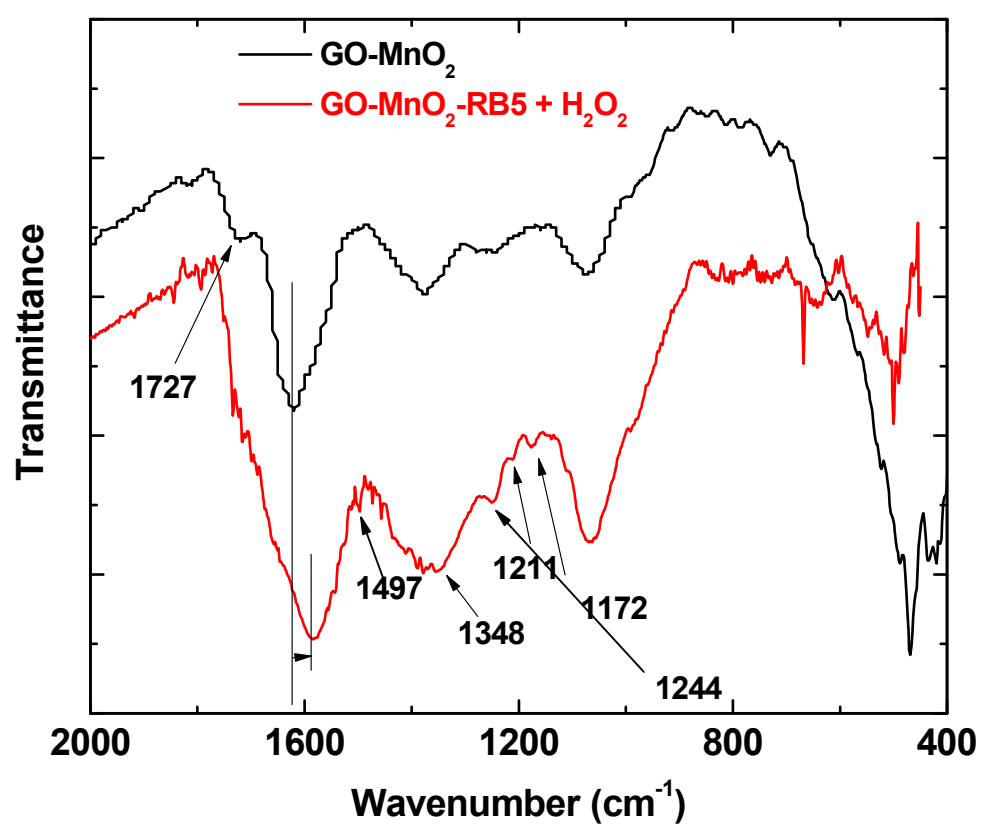

Figure 8. FTIR spectra of $\mathrm{GO}-\mathrm{MnO}_{2}$ before and after $\mathrm{RB} 5$ adsorption.

RB5 molecules present on the spent nanocomposites' surface caused a shift in the band attributed to the $\mathrm{C}=\mathrm{C}$ bond of the aromatic ring, indicative of adsorption through pi-pi interactions between the aromatic ring of the nanocomposites and the RB5 [66]. In the spectra of the nanocomposite after the adsorption/degradation of RB5, new bands appeared, indicating that new products were additionally formed as a result of the RB5 degradation. The new bands that appeared at $1074 \mathrm{~cm}^{-1}$ could be attributed to $\mathrm{C}=\mathrm{N}$, while the bands at 1244 and $1211 \mathrm{~cm}^{-1}$ to $\mathrm{C}-\mathrm{N}$ stretching and the shoulder at $1584 \mathrm{~cm}^{-1}$ could be attributed to N-H bending, indicating that primary amines were formed as a result of the cleavage of the $-\mathrm{N}=\mathrm{N}-$ bond of RB5 [60]. The bands at $1170 \mathrm{~cm}^{-1}$ revealed that there were surface species with sulfone and/or sulfonate groups indicative of RB5 degradation; the bands at about $1350 \mathrm{~cm}^{-1}$ could be also attributed to these groups. The increase in the band at about $718 \mathrm{~cm}^{-1}$, which was due to the out of plane deformation vibration of aromatic $\mathrm{C}-\mathrm{H}$ corresponding to parasubstituted aromatic rings, suggested that new degradation products accumulated on the catalyst' surface as a consequence of the oxidative reactions on the impregnated GO surface. These degradation products were adsorbed on the GO- $\mathrm{MnO}_{2}$ surface. The same results were presented by Mbarek et al. after the degradation of $\mathrm{RB} 5$ by $\mathrm{Mn}_{85} \mathrm{Al}_{15}$ particles. Méndez-Martınéz et al. also presented similar results [61] after the electrochemical treatment of the $\mathrm{RB} 5$ solution. For the spent $\mathrm{MnO}_{2}$, the bands at 1160 and $1117 \mathrm{~cm}^{-1}$ revealed that there were oxygen surface species that attributed to the sulfone and/or sulfonate groups, which was indicative of RB5 degradation. The bands at about $1360 \mathrm{~cm}^{-1}$ may have been due to these groups as well.

\subsection{Degradation Mechanism}

The GO- $\mathrm{MnO}_{2}$ nanocomposite presented a superior performance compared with the precursor materials. The contact between $\mathrm{MnO}_{2}$ nanoparticles and GO sheets prevented the $\mathrm{MnO}_{2}$ from leaching to the solution and efficiently catalyzed $\mathrm{H}_{2} \mathrm{O}_{2}$ to generate $\mathrm{OH}$ radicals, thus facilitating the dye degradation [67]. Dye molecules were initially adsorbed onto the GO surface by pi-pi conjugation mechanisms [68], as was revealed by FTIR results, and were degradated by $\mathrm{MnO}_{2}$. Small reaction products molecules, i.e., $\mathrm{SO}_{4}{ }^{2-}$ from the $\mathrm{RB} 5$ decomposition, were desorbed from the $\mathrm{MnO}_{2}$ surface, leading to the catalyst recovering [67]. Upon contact with the $\mathrm{GO}-\mathrm{MnO}_{2}$ acidic surface $(\mathrm{pH}=3)$, RB5 exchanged electrons with $\mathrm{MnO}_{2}$. RB5 degradation could be described by equations of redox reactions [63]: 


$$
\begin{aligned}
& \mathrm{Mn} \rightarrow \mathrm{Mn}^{2+}+2 \mathrm{e}^{-} \\
& 2 \mathrm{H}_{2} \mathrm{O} \rightarrow \mathrm{H}_{3} \mathrm{O}^{+}+\mathrm{OH}^{-} \\
& 2 \mathrm{H}_{3} \mathrm{O}^{+}+2 \mathrm{e}^{-} \rightarrow \mathrm{H}_{2}+2 \mathrm{H}_{2} \mathrm{O} \\
& \mathrm{R}-\mathrm{N}=\mathrm{N}-\mathrm{N}+\mathrm{H}_{2} \rightarrow \mathrm{R}-\mathrm{NH}-\mathrm{NH}-\mathrm{R} \\
& \mathrm{R}-\mathrm{NH}-\mathrm{NH}-\mathrm{R}+\mathrm{H}_{2} \rightarrow \mathrm{R}-\mathrm{NH}_{2}+\mathrm{R}-\mathrm{NH}_{2}
\end{aligned}
$$

In acidic environments, the concentration of $\mathrm{H}_{3} \mathrm{O}^{+}$increased, resulting in increased active $\mathrm{H}_{2}$ and thus improving the azo dye degradation. The active $\mathrm{H}_{2}$ was seen during the reaction as bubbles in the solution, while the presence of $\mathrm{OH}^{-}$ions (Equation (8)) resulted in a $\mathrm{pH}$ increase in the dye solution. The $\mathrm{pH}$ was found to increase after the degradation from the initial level 3 to about 6.2 and 6.8 in the solutions with $\mathrm{MnO}_{2}$ and GO-MnO${ }_{2}$ catalysts, respectively. It was concluded that $\mathrm{RB} 5$ degradation in the presence of either $\mathrm{MnO}_{2}$ or $\mathrm{GO}-\mathrm{MnO}_{2}$ was based on $\mathrm{H}_{2}$ release and cleavage of $-\mathrm{N}=\mathrm{N}-$ bonds to $-\mathrm{NH}_{2}$ groups.

$\mathrm{H}_{2} \mathrm{O}_{2}$ could increase the RB5 degradation due to a Fenton-like mechanism [69]. $\mathrm{H}_{2} \mathrm{O}_{2}$ could react with $\mathrm{Mn}$ ions, producing hydroxyl radicals that could attack and degrade the RB5 molecules according to the following equations [69]:

$$
\begin{aligned}
& \mathrm{Mn}(\mathrm{IV})+2 \mathrm{H}_{2} \mathrm{O} \rightarrow \mathrm{Mn}(\mathrm{IV})^{*} \mathrm{H}_{2} \mathrm{O}_{2} \rightarrow \mathrm{Mn}(\mathrm{II})+\mathrm{HO}_{2}{ }^{*}+\mathrm{H}^{+} \rightarrow 2 \mathrm{H}^{+}+\mathrm{O}_{2}{ }^{*} \\
& \mathrm{Mn}(\mathrm{II})+\mathrm{H}_{2} \mathrm{O}_{2} \rightarrow \mathrm{Mn}(\mathrm{IV})+\mathrm{HO}^{*}+\mathrm{OH}^{-} \\
& \mathrm{HO}^{*}\left(\mathrm{O}_{2}{ }^{{ }^{-}}\right)+\text {dye } \rightarrow \mathrm{CO}_{2}+\mathrm{H}_{2} \mathrm{O}
\end{aligned}
$$

The cleavage of the azo bonds could lead to the generation of alkylsulfonyl phenolic compounds since the hydroxyl radicals could destroy the conjugated pi-systems according to Figure 9:
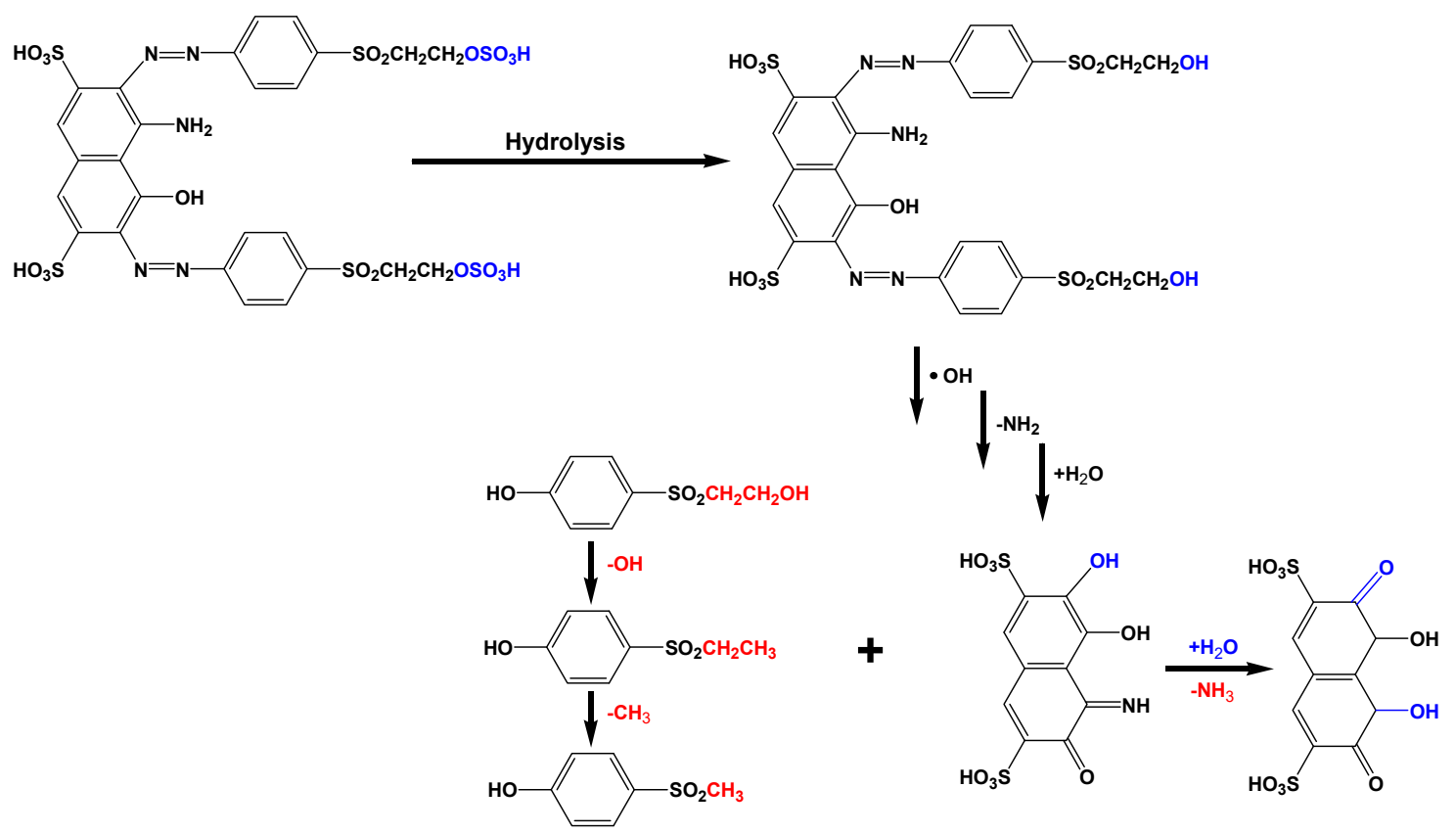

Figure 9. Possible mechanism of azo-bond cleavage in dye molecules.

The presence of graphene oxide supported the adsorption ability for RB5, indicating that having a rich surface chemistry with a sufficient amount of hydroxyl groups leads to a sufficient RB5 degradation. The modification of GO may be further examined for improvement of the degradation process.

\section{Conclusions}

GO proved to be an effective carbonaceous support for manganese oxide $\left(\mathrm{MnO}_{2}\right)$ for the preparation of a nanocomposite catalyst. The nanocomposite was tested for the degradation of RB5. 
The GO- $\mathrm{MnO}_{2}$ nanocomposite presented a high catalytic activity for the degradation/oxidation of RB5 in ambient conditions without light irradiation that reached equilibrium in $60 \mathrm{~min}$. The GO-MnO catalytic activity was higher than that of its precursor materials. The addition of $\mathrm{H}_{2} \mathrm{O}_{2}$ resulted in an increase in the removal/degradation of RB5. Degradation may have been due to the cleavage of the azo bonds for the formation of $-\mathrm{NH}_{2}$ groups, which led to the decolorization of the solution and the formation of new products as aromatic amines and amino-naphthalene sulfonates. The higher RB5 degradation presented by $\mathrm{GO}-\mathrm{MnO}_{2}$ nanocomposite was attributed to the presence of graphene oxide with a sufficient amount of hydroxyl groups, which led to a more sufficient RB5 degradation. The improved RB5 degradation presented by GO- $\mathrm{MnO}_{2}$ nanocomposite, which reached $98 \%$ removal/degradation with a $20 \%$ concentration of manganese oxide in the nanocomposite compared to $95 \%$ for pure manganese oxide, presented serious difficulties in the separation from aquatic solutions, making the GO a sufficient carbonaceous support for manganese oxide that improved the removal/degradation and the separation from the solution.

Author Contributions: This article was written by G.Z.K. and E.A.D. after personal invitation for the Special Issue "Wastewater Treatment Processes". H.S. contributed to the experimental design.

Funding: This research received no external funding.

Conflicts of Interest: The authors declare no conflict of interest.

\section{References}

1. Przystas, W.; Zablocka-Godlewska, E.; Grabinska-Sota, E. Biological removal of azo and triphenylmethane dyes and toxicity of process by-products. Water Air Soil Pollut. 2012, 223, 1581-1592. [CrossRef] [PubMed]

2. Chetima, A.; Wahabou, A.; Zomegni, G.; Rahman, A.N.; Nde, D.B. Bleaching of neutral cotton seed oil using organic activated carbon in a batch system: Kinetics and adsorption isotherms. Processes 2018, 6, 22. [CrossRef]

3. Di Marcoberardino, G.; Vitali, D.; Spinelli, F.; Binotti, M.; Manzolini, G. Green hydrogen production from raw biogas: A techno-economic investigation of conventional processes using pressure swing adsorption unit. Processes 2018, 6, 19. [CrossRef]

4. Yang, F.; Chen, S.; Shi, C.; Xue, F.; Zhang, X.; Ju, S.; Xing, W. A facile synthesis of hexagonal spinel $\lambda-\mathrm{MnO}_{2}$ ion-sieves for highly selective $\mathrm{Li}^{+}$adsorption. Processes 2018, 6, 59. [CrossRef]

5. You, Z.; Zhang, L.; Zhang, S.; Sun, Y.; Shah, K. Treatment of oil-contaminated water by modified polysilicate aluminum ferric sulfate. Processes 2018, 6, 95. [CrossRef]

6. Bian, Y.; Xiong, N.; Zhu, G. Technology for the remediation of water pollution: A review on the fabrication of metal organic frameworks. Processes 2018, 6, 122. [CrossRef]

7. Bafana, A.; Devi, S.S.; Chakrabarti, T. Azo dyes: Past, present and the future. Environ. Rev. 2011, 19, 350-370. [CrossRef]

8. Gupta, V.K.; Jain, R.; Mittal, A.; Saleh, T.A.; Nayak, A.; Agarwal, S.; Sikarwar, S. Photo-catalytic degradation of toxic dye amaranth on $\mathrm{TiO}_{2} / \mathrm{UV}$ in aqueous suspensions. Mater. Sci. Eng. C 2012, 32, 12-17. [CrossRef]

9. Gupta, V.K.; Jain, R.; Nayak, A.; Agarwal, S.; Shrivastava, M. Removal of the hazardous dye-tartrazine by photodegradation on titanium dioxide surface. Mater. Sci. Eng. C 2011, 31, 1062-1067. [CrossRef]

10. Vijayaraghavan, J.; Sardhar Basha, S.J.; Jegan, J. A review on efficacious methods to decolorize reactive azo dye. J. Urban Environ. Eng. 2013, 7, 30-47. [CrossRef]

11. Han, F.; Kambala, V.S.R.; Srinivasan, M.; Rajarathnam, D.; Naidu, R. Tailored titanium dioxide photocatalysts for the degradation of organic dyes in wastewater treatment: A review. Appl. Catal. A Gen. 2009, 359, $25-40$. [CrossRef]

12. Nakata, K.; Fujishima, A. $\mathrm{TiO}_{2}$ photocatalysis: Design and applications. J. Photochem. Photobiol. C Photochem. Rev. 2012, 13, 169-189. [CrossRef]

13. Rauf, M.A.; Ashraf, S.S. Fundamental principles and application of heterogeneous photocatalytic degradation of dyes in solution. Chem. Eng. J. 2009, 151, 10-18. [CrossRef] 
14. Yin, B.; Zhang, S.; Jiao, Y.; Liu, Y.; Qu, F.; Wu, X. Facile synthesis of ultralong $\mathrm{MnO}_{2}$ nanowires as high performance supercapacitor electrodes and photocatalysts with enhanced photocatalytic activities. CrystEngComm 2014, 16, 9999-10005. [CrossRef]

15. Caliskan, N.; Kul, A.R.; Alkan, S.; Sogut, E.G.; Alacabey, İ. Adsorption of Zinc(II) on diatomite and manganese-oxide-modified diatomite: A kinetic and equilibrium study. J. Hazard. Mater. 2011, 193, 27-36. [CrossRef] [PubMed]

16. Mei, J.; Zhang, L.; Niu, Y. Fabrication of the magnetic manganese dioxide/graphene nanocomposite and its application in dye removal from the aqueous solution at room temperature. Mater. Res. Bull. 2015, 70, 82-86. [CrossRef]

17. Tang, J.; Mu, B.; Wang, W.; Zheng, M.; Wang, A. Fabrication of manganese dioxide/carbon/attapulgite composites derived from spent bleaching earth for adsorption of $\mathrm{Pb}(\mathrm{II})$ and brilliant green. $\mathrm{RSC}$ Adv. 2016, 6, 36534-36543. [CrossRef]

18. Debnath, B.; Roy, A.S.; Kapri, S.; Bhattacharyya, S. Efficient dye degradation catalyzed by manganese oxide nanoparticles and the role of cation valence. ChemistrySelect 2016, 1, 4265-4273. [CrossRef]

19. Chacón-Patiño, M.L.; Blanco-Tirado, C.; Hinestroza, J.P.; Combariza, M.Y. Biocomposite of nanostructured $\mathrm{MnO}_{2}$ and fique fibers for efficient dye degradation. Green Chem. 2013, 15, 2920-2928. [CrossRef]

20. Das, S.; Samanta, A.; Jana, S. Light-assisted synthesis of hierarchical flower-like $\mathrm{MnO}_{2}$ nanocomposites with solar light induced enhanced photocatalytic activity. ACS Sustain. Chem. Eng. 2017, 5, 9086-9094. [CrossRef]

21. Zhang, Y.X.; Guo, X.L.; Huang, M.; Hao, X.D.; Yuan, Y.; Hua, C. Engineering birnessite-type $\mathrm{MnO}_{2}$ nanosheets on fiberglass for $\mathrm{pH}$-dependent degradation of methylene blue. J. Phys. Chem. Solids 2015, 83, 40-46. [CrossRef]

22. Vandenbroucke, A.M.; Mora, M.; Jiménez-Sanchidrián, C.; Romero-Salguero, F.J.; De Geyter, N.; Leys, C.; Morent, R. Tce abatement with a plasma-catalytic combined system using $\mathrm{MnO}_{2}$ as catalyst. Appl. Catal. B Environ. 2014, 156-157, 94-100. [CrossRef]

23. Liang, H.; Sun, H.; Patel, A.; Shukla, P.; Zhu, Z.H.; Wang, S. Excellent performance of mesoporous $\mathrm{Co}_{3} \mathrm{O}_{4} / \mathrm{MnO}_{2}$ nanoparticles in heterogeneous activation of peroxymonosulfate for phenol degradation in aqueous solutions. Appl. Catal. B Environ. 2012, 127, 330-335. [CrossRef]

24. Adán-Más, A.; Wei, D. Photoelectrochemical properties of graphene and its derivatives. Nanomaterials 2013, 3, 325-356. [CrossRef] [PubMed]

25. Dreyer, D.R.; Park, S.; Bielawski, C.W.; Ruoff, R.S. The chemistry of graphene oxide. Chem. Soc. Rev. 2010, 39, 228-240. [CrossRef]

26. Krishnamoorthy, K.; Veerapandian, M.; Yun, K.; Kim, S.J. The chemical and structural analysis of graphene oxide with different degrees of oxidation. Carbon 2013, 53, 38-49. [CrossRef]

27. Yu, J.; Huang, H.; Gan, Y.; Xia, Y.; Liang, C.; Zhang, J.; Tao, X.; Zhang, W. A new strategy for the construction of $3 \mathrm{D} \mathrm{TiO} 2$ nanowires/reduced graphene oxide for high-performance lithium/sodium batteries. J. Mater. Chem. A 2018, 6, 24256-24266. [CrossRef]

28. Fei, F.; Cseri, L.; Szekely, G.; Blanford, C.F. Robust covalently cross-linked polybenzimidazole/graphene oxide membranes for high-flux organic solvent nanofiltration. ACS Appl. Mater. Interfaces 2018, 10, 16140-16147. [CrossRef]

29. Cseri, L.; Baugh, J.; Alabi, A.; AlHajaj, A.; Zou, L.; Dryfe, R.A.W.; Budd, P.M.; Szekely, G. Graphene oxide-polybenzimidazolium nanocomposite anion exchange membranes for electrodialysis. J. Mater. Chem. A 2018, 6, 24728-24739. [CrossRef]

30. Chen, W.; Li, D.; Tian, L.; Xiang, W.; Wang, T.; Hu, W.; Hu, Y.; Chen, S.; Chen, J.; Dai, Z. Synthesis of graphene quantum dots from natural polymer starch for cell imaging. Green Chem. 2018, 20, 4438-4442. [CrossRef]

31. He, Y.; Chen, W.; Li, X.; Zhang, Z.; Fu, J.; Zhao, C.; Xie, E. Freestanding three-dimensional graphene $/ \mathrm{MnO}_{2}$ composite networks as ultralight and flexible supercapacitor electrodes. ACS Nano 2013, 7, 174-182. [CrossRef]

32. Hu, M.; Hui, K.S.; Hui, K.N. Role of graphene in $\mathrm{MnO}_{2}$ /graphene composite for catalytic ozonation of gaseous toluene. Chem. Eng. J. 2014, 254, 237-244. [CrossRef]

33. Hummers, W.S., Jr.; Offeman, R.E. Preparation of graphitic oxide. J. Am. Chem. Soc. 1958, 80, 1339. [CrossRef]

34. Ma, S.-B.; Ahn, K.-Y.; Lee, E.-S.; Oh, K.-H.; Kim, K.-B. Synthesis and characterization of manganese dioxide spontaneously coated on carbon nanotubes. Carbon 2007, 45, 375-382. [CrossRef] 
35. Ma, L.; Shen, X.; Ji, Z.; Zhu, G.; Zhou, H. Ag nanoparticles decorated $\mathrm{MnO}_{2} /$ reduced graphene oxide as advanced electrode materials for supercapacitors. Chem. Eng. J. 2014, 252, 95-103. [CrossRef]

36. Vieira, R.S.; Beppu, M.M. Interaction of natural and crosslinked chitosan membranes with $\mathrm{Hg}$ (II) ions. Colloid Surf. A 2006, 279, 196-207. [CrossRef]

37. Lagergren, S. About the theory of so-called adsorption of soluble substances. Handlingar 1898, 24, 1-39.

38. Ho, Y.S.; Ng, J.C.Y.; McKay, G. Kinetics of pollutant sorption by biosorbents: Review. Sep. Purif. Methods 2000, 29, 189-232. [CrossRef]

39. Kim, I.-T.; Kouda, N.; Yoshimoto, N.; Morita, M. Preparation and electrochemical analysis of electrodeposited $\mathrm{MnO}_{2} / \mathrm{C}$ composite for advanced capacitor electrode. J. Power Sources 2015, 298, 123-129. [CrossRef]

40. Liu, S.; Li, H.; Yan, L. Synthesis and photocatalytic activity of three-dimensional ZnS/CdS composites. Mater. Res. Bull. 2013, 48, 3328-3334. [CrossRef]

41. Zhu, H.T.; Luo, J.; Yang, H.X.; Liang, J.K.; Rao, G.H.; Li, J.B.; Du, Z.M. Birnessite-type $\mathrm{MnO}_{2}$ nanowalls and their magnetic properties. J. Phys. Chem. C 2008, 112, 17089-17094. [CrossRef]

42. Wu, Z.-S.; Ren, W.; Wang, D.-W.; Li, F.; Liu, B.; Cheng, H.-M. High-energy $\mathrm{MnO}_{2}$ nanowire/graphene and graphene asymmetric electrochemical capacitors. ACS Nano 2010, 4, 5835-5842. [CrossRef]

43. Qu, J.; Shi, L.; He, C.; Gao, F.; Li, B.; Zhou, Q.; Hu, H.; Shao, G.; Wang, X.; Qiu, J. Highly efficient synthesis of graphene $/ \mathrm{MnO}_{2}$ hybrids and their application for ultrafast oxidative decomposition of methylene blue. Carbon 2014, 66, 485-492. [CrossRef]

44. Seredych, M.; Bandosz, T.J. Evaluation of $\mathrm{GO} / \mathrm{MnO}_{2}$ composites as supercapacitors in neutral electrolytes: Role of graphite oxide oxidation level. J. Mater. Chem. 2012, 22, 23525-23533. [CrossRef]

45. Tian, H.; He, J.; Liu, L.; Wang, D.; Hao, Z.; Ma, C. Highly active manganese oxide catalysts for low-temperature oxidation of formaldehyde. Micropor. Mesopor. Mater. 2012, 151, 397-402. [CrossRef]

46. Jeong, Y.U.; Manthiram, A. Nanocrystalline manganese oxides for electrochemical capacitors with neutral electrolytes. J. Electrochem. Soc. India 2002, 149, A1419-A1422. [CrossRef]

47. Seredych, M.; Bandosz, T.J. Manganese oxide and graphite oxide $/ \mathrm{MnO}_{2}$ composites as reactive adsorbents of ammonia at ambient conditions. Micropor. Mesopor. Mater. 2012, 150, 55-63. [CrossRef]

48. Feng, Q.; Kanoh, H.; Miyai, Y.; Ooi, K. Metal ion extraction/insertion reactions with todorokite-type manganese oxide in the aqueous phase. Chem. Mater. 1995, 7, 1722-1727. [CrossRef]

49. Oba, M.; Oaki, Y.; Imai, H. A microbial-mineralization-inspired approach for synthesis of manganese oxide nanostructures with controlled oxidation states and morphologies. Adv. Funct. Mater. 2010, 20, 4279-4286. [CrossRef]

50. Lin, S.-S.; Gurol, M.D. Catalytic decomposition of hydrogen peroxide on iron oxide: Kinetics, mechanism, and implications. Environ. Sci. Technol. 1998, 32, 1417-1423. [CrossRef]

51. Xu, L.; Xu, C.; Zhao, M.; Qiu, Y.; Sheng, G.D. Oxidative removal of aqueous steroid estrogens by manganese oxides. Water Res. 2008, 42, 5038-5044. [CrossRef] [PubMed]

52. Garcia, J.; Boroski, M.; da Silva, A.; Oliviera, J.; Nozaki, J.; Barreto, W. Solar and Trends in Solar Energy Research; Hough, T.P., Ed.; Nova Science Publishers: New York, NY, USA, 2006; pp. 107-132.

53. Karadag, D.; Turan, M.; Akgul, E.; Tok, S.; Faki, A. Adsorption equilibrium and kinetics of Reactive Black 5 and Reactive Red 239 in aqueous solution onto surfactant-modified zeolite. J. Chem. Eng. Data 2007, 52, 1615-1620. [CrossRef]

54. Bautista-Toledo, M.I.; Rivera-Utrilla, J.; Ocampo-Pérez, R.; Carrasco-Marín, F.; Sánchez-Polo, M. Cooperative adsorption of bisphenol-A and chromium(III) ions from water on activated carbons prepared from olive-mill waste. Carbon 2014, 73, 338-350. [CrossRef]

55. Wolfenden, B.S.; Willson, R.L. Radical-cations as reference chromogens in kinetic studies of ono-electron transfer reactions: Pulse radiolysis studies of 2,2'-azinobis-(3-ethylbenzthiazoline-6-sulphonate). J. Chem. Soc. Perkin Trans. 1982, 2, 805-812. [CrossRef]

56. Cao, J.; Wei, L.; Huang, Q.; Wang, L.; Han, S. Reducing degradation of azo dye by zero-valent iron in aqueous solution. Chemosphere 1999, 38, 565-571. [CrossRef]

57. Nam, S.; Tratnyek, P.G. Reduction of azo dyes with zero-valent iron. Water Res. 2000, 34, 1837-1845. [CrossRef]

58. Feng, W.; Nansheng, D.; Helin, H. Degradation mechanism of azo dye C.I. Reactive red 2 by iron powder reduction and photooxidation in aqueous solutions. Chemosphere 2000, 41, 1233-1238. [CrossRef] 
59. Stylidi, M.; Kondarides, D.I.; Verykios, X.E. Pathways of solar light-induced photocatalytic degradation of azo dyes in aqueous $\mathrm{TiO}_{2}$ suspensions. Appl. Catal. B Environ. 2003, 40, 271-286. [CrossRef]

60. Bradu, C.; Frunza, L.; Mihalche, N.; Avramescu, S.-M.; Neaţă, M.; Udrea, I. Removal of Reactive Black 5 azo dye from aqueous solutions by catalytic oxidation using $\mathrm{CuO} / \mathrm{Al}_{2} \mathrm{O}_{3}$ and $\mathrm{NiO} / \mathrm{Al}_{2} \mathrm{O}_{3}$. Appl. Catal. B Environ. 2010, 96, 548-556. [CrossRef]

61. Méndez-Martínez, A.J.; Dávila-Jiménez, M.M.; Ornelas-Dávila, O.; Elizalde-González, M.P.; Arroyo-Abad, U.; Sirés, I.; Brillas, E. Electrochemical reduction and oxidation pathways for Reactive Black 5 dye using nickel electrodes in divided and undivided cells. Electrochim. Acta 2012, 59, 140-149. [CrossRef]

62. Zhang, M.; Lei, D.; Du, Z.; Yin, X.; Chen, L.; Li, Q.; Wang, Y.; Wang, T. Fast synthesis of $\mathrm{SnO}_{2} /$ graphene composites by reducing graphene oxide with stannous ions. J. Mater. Chem. 2011, 21, 1673-1676. [CrossRef]

63. Ben Mbarek, W.; Azabou, M.; Pineda, E.; Fiol, N.; Escoda, L.; Suñol, J.J.; Khitouni, M. Rapid degradation of azo-dye using Mn-Al powders produced by ball-milling. RSC Adv. 2017, 7, 12620-12628. [CrossRef]

64. Liang, S.; Teng, F.; Bulgan, G.; Zong, R.; Zhu, Y. Effect of phase structure of $\mathrm{MnO}_{2}$ nanorod catalyst on the activity for CO oxidation. J. Phys. Chem. C 2008, 112, 5307-5315. [CrossRef]

65. Vázquez-Olmos, A.; Redón, R.; Rodríguez-Gattorno, G.; Esther Mata-Zamora, M.; Morales-Leal, F.; Fernández-Osorio, A.L.; Saniger, J.M. One-step synthesis of $\mathrm{Mn}_{3} \mathrm{O}_{4}$ nanoparticles: Structural and magnetic study. J. Colloid Interface Sci. 2005, 291, 175-180. [CrossRef] [PubMed]

66. Bele, S.; Samanidou, V.; Deliyanni, E. Effect of the reduction degree of graphene oxide on the adsorption of bisphenol A. Chem. Eng. Res. Des. 2016, 109, 573-585. [CrossRef]

67. Li, Y.; Qu, J.; Gao, F.; Lv, S.; Shi, L.; He, C.; Sun, J. In situ fabrication of $\mathrm{Mn}_{3} \mathrm{O}_{4}$ decorated graphene oxide as a synergistic catalyst for degradation of methylene blue. Appl. Catal. B Environ. 2015, 162, 268-274. [CrossRef]

68. Travlou, N.A.; Kyzas, G.Z.; Lazaridis, N.K.; Deliyanni, E.A. Graphite oxide/chitosan composite for reactive dye removal. Chem. Eng. J. 2013, 217, 256-265. [CrossRef]

69. Ramesh, M.; Nagaraja, H.S.; Rao, M.P.; Anandan, S.; Huang, N.M. Fabrication, characterization and catalytic activity of $\alpha-\mathrm{MnO}_{2}$ nanowires for dye degradation of Reactive Black 5. Mater. Lett. 2016, 172, 85-89. [CrossRef] 